УДК : 327.82

\title{
ХОРВАТСЬКІ УРОКИ ДЛЯ УКРАЇНИ: ДЕОКУПАЦІЯ, РЕІНТЕГРАЦІЯ ТА РОЗБУДОВА МИРУ
}

\section{Семчинський Костянтин Валерійович}

Надіслано:

15.10 .2020

кандидат філософських наук, доцент,

Рецензовано:

Київський національний університет культури і мистецтв,

28.10 .2020

м. Київ, Україна

ORCID: 0000-0002-3125-3401

Прийнято:

semchynskyy@gmail.com

06.11 .2020

Автором досліджуються особливості процесів деокупації, реінтеграції та розбудови миру, що відбувалися у Хорватії наприкінці 1990-хрр., та аналізуються можливості реалізації хорватського досвіду в Україні. Метою дослідження $\epsilon$ з'ясування специфіки хорватської стратегії розбудови миру, iii особливостей i факторів ефективності та визначення можливостей застосування хорватської моделі розбудови миру, окремих її елементів у процесі реінтеграції нині окупованих українських територій. Застосувавши історичні, аналітичні і компаративні методи, автор робить висновок про те, що не всі засоби деокупації та реінтеграції територій, що мали успіх у хорватському кейсі, можуть бути настільки ж ефективними за сучасних українських реалій. У результаті дослідження визначено, що основним фактором ефективності хорватської моделі розбудови миру стала наявність суспільного консенсусу щодо пріоритету цілісності держави і засобів для відновлення суверенітету над усією її територією. У висновках зазначено, що ефективна розбудова миру на деокупованих та реінтегрованих територіях передбачає поширення українських культурно-ціннісних домінант, українізацію інформаційно-культурного простору та освітньо-виховної системи.

Ключові слова: деокупація; реінтеграція; розбудова миру; хорватська модель.

Semchynskyy Kostiantyn, Candidate of Philosophy, Associate Professor, Kyiv National University of Culture and Arts, Kyiv, Ukraine

\section{Croatian Lessons for Ukraine: De-occupation, Reintegration and Peace-Building}

The author examines the features of the processes of de-occupation, reintegration and peace-building that took place in Croatia in the late 1990s and analyzes the possibilities of implementing the Croatian experience in Ukraine. 
The aim of the study is to clarify the specifics of the Croatian peace building strategy, its features and effectiveness factors and to determine the possibilities of applying the Croatian model of peace-building and its individual elements in the process of reintegration of the currently occupied Ukrainian territories. Applying historical, analytical and comparative methods, the author concludes that not all means of de-occupation and reintegration of territories that have been successful in the Croatian case can be as effective in modern Ukrainian realities. The study found that the main factor in the effectiveness of the Croatian model of peace-building was the presence of public consensus on the priority of the integrity of the state and the means to restore sovereignty over its entire territory. The conclusions revealed that the effective development of peace in the occupied and reintegrated territories involves the spread of Ukrainian cultural and value dominants, the Ukrainianization of information and cultural space and the educational system.

Key words: de-occupation; reintegration; peace-building; Croatian model.

Семчинский Константин Валерьевич, кандидат философских наук, доцент, Киевский национальный университет культуры и искусств, г. Киев, Украина

\section{Хорватские уроки для Украины: деоккупация, реинтеграция и строительство мира}

Автором исследуются особенности процессов деоккупации, реинтеграции и развития мира, которые происходили в Хорватии в кон. 1990-х гг. и анализируются возможности реализации хорватского опыта в Украине. Целью исследования является выяснение специфики хорватской стратегии развития мира, ее особенностей и факторов эффективности и определения возможностей применения хорватской модели развития мира и отдельных ее элементов в процессе реинтеграции ныне оккупированных украинских территорий. Применив исторические, аналитические и компаративные методы, автор делает вывод о том, что не все средства деоккупации и реинтеграции территорий, имевших успех в хорватском кейсе, могут быть столь же эффективными в современных украинских реалиях. В результате исследования установлено, что основным фактором эффективности хорватской модели развития мира стало наличие общественного консенсуса относительно приоритета целостности государства и средств для восстановления суверенитета на всей ее территории. В выводах обнаружено, что эффективное развитие мира на деоккупированных и реинтегрированых территориях предусматривает распространение украинских культурно-ценностных доминант, украинизацию информационнокультурного пространства и образовательно-воспитательной системы. 
Ключевые слова: деоккупация; реинтеграция; развитие мира; хорватская модель.

\section{Вступ}

Наприкінці 1990-х рр. Республіка Хорватія ефективно реалізувала план деокупації та реінтегації відторгнутих упродовж війни за незалежність територій і створила умови для успішного постконфліктного примирення. Хорватський досвід мирної реінтеграції територій та розбудови миру (реасеbuilding) може бути корисним для України. Актуальним є дослідження засобів, особливостей та причин успіху хорватської моделі - стратегії розбудови миру на деокупованих реінтегрованих територіях та можливості застосування їі елементів в українських реаліях.

\section{Аналіз останніх досліджень і публікацій}

Після 2014 р. науковий інтерес до проблеми реінтегації тимчасово окупованих українських територій детермінував появу низки праць, які досліджували можливості, варіанти, сценарії цих процесів і пропонували дороговкази відновлення цілісності української держави та алгоритми подолання наслідків гібридної війни РФ проти України (NISD, Ukrainian Prism Foreign Policy Council). Водночас хорватська модель реінтеграції деокупованих територій і постконфліктного примирення була предметом дослідження як вітчизняних (А. Демещук, О.Левченко, Є. Магда), так і зарубіжних (H. Bozhichevich) фахівців із розбудови миру. Проте компаративний аналіз миротворчих технологій з урахуванням ціннісно-культурних особливостей нині окупованих українських територій за умов гібридної війни постає наразі актуальним.

\section{Формулювання цілей статті}

Автор ставить за мету виявити фактори ефективності хорватської стратегії розбудови миру, їі особливості, сильні та слабкі сторони; дослідити можливості застосування хорватської моделі розбудови миру та окремих iї елементів у процесі реінтеграції нині окупованих українських територій; визначити, чи можуть ті чи інші засоби розбудови миру, що мали успіх у хорватському кейсі, бути настільки ж ефективними в сучасних українських реаліях.

\section{Виклад основного матеріалу дослідження}

У 1990-х рр. Республіка Хорватія зазнала агресії і змушена була захищати незалежність, боротися із сепаратизмом на своїй території і врешті силою зброї відновивши на ній суверенітет із 1995 р. розпочала тривалий і складний процес розбудови миру, що включав реінтеграцію деокупованих територій та примирення між сторонами насильницького конфлікту. Ненасильницький характер реінтеграції деокупованих регіонів дозволив уникнути жертв і відкрив 
шлях до мирного співіснування колишніх сторін конфлікту. I хоча процес примирення між цими сторонами триває й нині, можна констатувати, що від успішно реалізованої програми розбудови миру у виграші залишилися всі.

Хорватський інструментарій розбудови миру на деокупованих територіях включає такі елементи, які варто взяти на озброєння українському політикуму для вирішення проблеми цілісності держави: 1) проведення успішних військових операцій задля встановлення повного контролю над кордонами держави; 2) залучення міжнародного контингенту для підтримання миру; 3) забезпечення прав населення на повернених територіях; 4) демілітаризація і роззброєння воєнізованих формувань; 5) створення перехідної адміністрації на деокупованих територіях; 6) економічна підтримка ініціатив (викуп зброї, забезпечення як виїзду з країни, так і повернення тимчасово переміщених осіб на деокуповані території тощо).

У ході військово-поліцейських операцій «Блискавка» та «Буря» у травні і серпні 1995 р., відповідно, було практично відновлено територіальну цілісність Хорватії внаслідок ліквідації самопроголошеної Республіки Сербська Крайна (далі - РСК), що підтримувалася Белградом і займала близько 30 \% території держави. Проте на крайньому сході Хорватії, вздовж Дунаю на кордоні з Сербією, залишився останній анклав РСК - зайнята сербськими сепаратистами область Східної Славонії, Бараньї та Західного Срему (загальна назва - Східна Славонія або Хорватське Подунав'я). Хорватська влада всупереч суспільному запиту на військовий сценарій деокупації цього регіону вирішила повернути Східну Славонію мирним шляхом. Водночас, процес реінтеграції відбувався з позиції переможця, на хорватських умовах, проте з гарантіями національних прав місцевого сербського населення. 12 листопада 1995 р. сторонами було підписано Ердутську угоду («Основна угода про Східну Славонію, Баранью і Західний Срем»), що юридично оформила початок процесу реінтеграції Хорватського Подунав'я і включала 14 пунктів, 7 із яких стосувалися тих чи інших аспектів захисту прав людини. Ця угода була визнана Радою Безпеки ООН, яка Резолюцією 1037 створила Перехідну адміністрацію Організації Об’єднаних Націй для Східної Славонії, Бараньї і Західного Срема (англ. United Nations Transitional Authority for Eastern Slavonia, Baranja and Western Sirmium (UNTAES) для управління цією територією в перехідний період, а також передбачала «надсилання міжнародних сил, які в перехідний період підтримуватимуть мир та безпеку й допомагатимуть виконанню цієї Угоди. При цьому зазначена вище територія повинна бути демілітаризована, а демілітаризація здійснена протягом 30 днів після розміщення миротворчих сил. Демілітаризація охоплювала всі військові сили, зброю і поліцію, окрім міжнародного контингенту військ і поліції, що діяв під наглядом та згодою Перехідної адміністрації. Крім того, передбачалося, що Перехідна адміністрація уможливить повернення біженців 
та переміщених осіб до своїх помешкань, які користуватимуться тими ж правами, що й інші жителі території» (Levchenko, 2018).

Варто зауважити, що у 1995-1998 pp. центральне югославське керівництво «не було зацікавлене у загостренні ситуації у сусідній Хорватії та новому розпалюванню конфлікту на своєму західному кордоні» (Demeschuk, 2018 , р. 178) через низку внутрішньополітичних проблем і зовнішньополітичних викликів. Цим і обумовлюється поміркованість Белграда щодо хорватської реінтеграції Східної Славонії. Незважаючи на подібність політико-ідеологічних наративів («рускій мір» і «велика Сербія») i засобів реалізації політики гібридними методами, опоненти Хорватії та України різняться як військовосиловими характеристиками, так і економічним та міжнародно-політичним потенціалом. I Югославія кін. 1990-х pp., і сучасна РФ перебувають під міжнародними санкціями у ролі країн-ізгоїв. Але на відміну від Мілошевича, Путін не відмовиться від підтримки анексованих і окупованих Росією українських територій і від узалежнення всієї України в майбутньому. Росія протидіятиме встановленню української влади по всій території нашої держави, а Україна муситиме зважати і на характер ворога, i на характер гібридного протистояння, яке нав'язуватиме ворог, i на характер детермінованих ним в контексті цього гібридного протистояння загроз.

Хорватський досвід ілюструє, що власне деокупація може мати декілька версій - від наступальних операцій до довготривалої присутності миротворчої місії ООН та створення тимчасової адміністрації (Bezpechna reintehratsiia..., 2019). Перші дві миротворчі місії у Хорватії не дали позитивних результатів, що стало поштовхом до проведення деокупаційних операцій «Блискавка» та «Буря». Лише третя місія з мандатом Радбезу ООН на чолі з американським генералом Ж. П.Кляйном стала успішною в процесі розбудови миру. Однією із ініціатив Кляйна стало створення тимчасової місцевої поліції із сербів, хорватів та представників ООН, що сприяло зменшенню на індивідуальному рівні ворожості у стосунках між сторонами недавнього насильницького конфлікту і процесу примирення між хорватами і сербами на суспільному рівні. Український кейс об'єктивно не передбачає примирення із Росією у найближчій перспективі, проте за мету ставиться розбудова миру і примирення між сегментами українського суспільства, фактично між громадянами, які зазнали агресії та окупації територій їхнього проживання і громадянами, які уникнули подібної долі. При цьому серед перших є чимало колаборантів, сепаратистів і проксі, які чинитимуть опір деокупації та реінтеграції Криму й ОРДЛО, а серед других - радикально налаштованих осіб, які віддаватимуть перевагу насильницьким засобам реінтеграції замість мирних, каратимуть населення за перебування під окупацією в дусі сталінських спецслужб під час Другої світової війни. Тому питання про готовність МВС України утворити підрозділи 
3 колишніх міліціонерів, т. зв. «народних республік» та поліцейських України для спільного патрулювання i підтримання громадського порядку на деокупованих територіях, залишається відкритим, так само, як і питання реакції українського суспільства на подібну ініціативу.

Варто наголосити, що деокупація та реінтеграція - це «різні за строками, виконавцями та кінцевою метою процеси, хоча й тісно пов'язані між собою. Тому стратегії, спрямовані на досягнення цих цілей, мають передбачати чітку послідовність кроків і заходів, спрямованих на посилення позицій України i, відповідно, послаблення спроможностей держави-агресора та ефективності іï впливу на жителів тимчасово окупованих територій» (Pereosmyslennia deokupatsiinoi polityky..., 2020, p.140). Деокупація полягає у звільненні окупованих територій держави силами армії, поліції та спеціальних служб. Реінтеграція, зі свого боку, є процесом повернення деокупованих територій в політико-правовий, економічно-соціальний $\mathrm{i}$ культурно-інформаційний простір держави.

Що стосується деокупації, наша держава потребує міжнародної військової місії, яка матиме право на застосовування сили задля попередження чергової хвилі ескалації з боку Росії, тобто зможе встановити т. зв. «негативний» мир через припинення бойових дій без примирення між його сторонами. Своєю чергою, процес постконфліктного примирення має мінімізувати негативні наслідки російської агресії і створити умови для розбудови позитивного миру комплексу суспільних взаємодій, управлінських структур і механізмів контролю, за яких конфлікти врегульовуються на ранній стадії або взагалі не виникають. Водночас, на думку авторів аналітичної доповіді «Переосмислення деокупаційної політики України в рамках гібридної війни Росії проти України», «доведена низька ефективність міжнародних місій у разі їх розгортання на лінії розмежування. Остання істотно підважує успішність таких місій в цілому (незалежно від їх мандату): такі місії на лінії розмежування лише сприяють фіксації «окремого» існування «сепаратистських анклавів», та є фактором стримування - «заморожування», але не деокупації (i тим більше, не реінтеграції окупованих територій)». (Pereosmyslennia deokupatsiinoi polityky..., 2020, p. 153). Для ефективної деокупації недостатнім буде лише залучення міжнародної військової місії на лінії розмежування: політично та економічно підтримувані та підживлювані Росією сепаратисти чинитимуть опір деокупації. Тому Україна має позбавити сепаратистів контролю над ресурсами, які економічно та фінансово забезпечують існування «народних республік».

Першочерговим завданням деокупації та подальшої реінтегації тимчасово окупованих територій (далі - ТОТ) $є$ встановлення українського контролю над російсько-українським кордоном. Адже «без встановлення контролю над українсько-російським кордоном (у т. ч. - морським), не може 
бути й мови про проведення виборів/референдумів (чи їх визнання) в ОРДЛО чи Криму, як і залучення представників ОРДЛО в якості повноправних учасників переговорів у ТКГ (Тристоронній контактній групі - Авт.), роботі Спільного центру координації та контролю (СЦКК) тощо. Без повернення ТОТ під юрисдикцію України неможливе забезпечення прав і основних свобод людини» (Pereosmyslennia deokupatsiinoi polityky..., 2020, p. 135). Мусимо констатувати також відсутність перспектив проведення виборів в ОРДЛО без попереднього роззброєння або ліквідації бойовиків. Вважаємо контрпродуктивним повернення територій без попереднього знищення терористів на цій території, тому реінтеграція без деокупації неможлива.

Встановлення українського контролю над російсько-українським кордоном є необхідним і для успішної демілітаризації ТОТ. Взяття під контроль ЗСУ арсеналів озброєння і боєприпасів незаконних збройних формувань i виведення важкого озброєння постає в цьому контексті надважливим завданням. Водночас відкритим залишається питання про готовність Міністерства оборони провести кампанію добровільної здачі зброї за хорватським зразком - анонімно та з виплатою грошової винагороди за кожну одиницю, незалежно від технічного стану. У Хорватії це робили вже після того, як взяли під контроль кордон із Сербією, щоб не викуповувати зброю у тих самих людей по декілька разів.

Процес реінтеграції в єдиний конституційний простір України тимчасово окупованих територій України та населення, що на них проживає, має сприяти реалізації прав і свобод внутрішньо переміщених осіб з тимчасово окупованих територій України та створенню умов для добровільного повернення таких осіб до покинутого місця проживання (реінтеграція) або інтеграції за новим місцем проживання в Україні. Для порівняння проаналізуємо, як подібні процеси відбувалися в Хорватії. Аби уникнути наслідків масштабної гуманітарної кризи на деокупованих територіях колишньої РСК внаслідок втечі близько 200 тис. сербських біженців, офіційний Загреб вжив низку кроків з метою реінтегрувати ці території, а також Східну Славонію до Хорватії. Заради відновлення цілісності держава виявилася готовою створити необхідні умови для повернення біженців, вести діалог з переселенцями і задовольняти їхні потреби. Передбачалося виділення державної матеріальної допомоги для повернення сербських та хорватських біженців, створення спеціальної агенції, яка «сприяла продажукупівлі майна тих, хто залишив межі країни через етнічний конфлікт, та тих, хто, навпаки, хоче повернутися» (Levchenko, 2017). Сербам, які не бажали жити у Хорватії, дозволили продати свою нерухомість за ринковими довоєнними цінами (Tarasov, 2019). За процесом обміну житлом, який здійснювався людьми з Хорватії, Сербії та Боснії, уважно пильнували компетентні та контролюючі органи, аби він не перетворився у легальну форму етнічної чистки. 
Важливе значення для успішної реінтеграції мало юридичне визнання (конвалідація) виданих окупаційною владою документів і видача хорватських паспортів населенню деокупованих територій колишньої РСК і мешканцям Хорватського Подунав'я.

Апробований під час врегулювання низки конфліктів по всьому світу алгоритм розбудови миру у розділених насильницьким конфліктом суспільствах включає комплекс заходів, що мають на меті зменшення ризику виникнення чи відновлення конфлікту, посилення інституційних механізмів на всіх рівнях для вирішення конфлікту та встановлення основ для сталого миру і розвитку. у Хорватії передбачалося створення дитсадків і шкіл із сербською мовою навчання, що мало позитивний ефект для розбудови миру $\mathrm{i}$ загальнонаціонального примирення у країні. Проте цей елемент не можна застосувати в українському випадку. Використання та популярність російськомовних медіаплатформ значною мірою визначає ступінь вразливості населення до кремлівських наративів. Тому у процесі розбудови миру на Донбасі важливе значення матиме усунення російськомовного контенту як елементу гібридної агресії і загрози національним інтересам України із інформаційного простору щойно деокупованих територій. Деокупація та реінтеграція тимчасово окупованих регіонів нашої держави мають відбуватися за домінантної екстраполяції українського культурно-ціннісного коду.

Повернення до мирного життя учасників незаконних збройних формувань має включати амністію для тих, хто не скоював воєнних злочинів та створення можливостей для полегшення їхньої адаптації до мирного життя. Україна має створити спеціальні центри підготовки для освоєння колишніми бойовиками робітничих і будівельних професій, аби забезпечити їх роботою 3 подальшими перспективами і грошовим забезпеченням. Як переконливо доводить хорватський досвід, у виборах на деокупованих територіях повинні брати участь не лише тамтешні мешканці, але й ті, хто був змушений залишити місце проживання під час війни, а перед проведенням виборів до місцевих органів влади мають бути створені детальні списки виборців. Проте, якщо хорватська модель розбудови миру передбачала квоти для сербів у парламенті та міністерствах, в українських реаліях мусить бути «певний перехідний період (від 5 до 15 років), протягом якого буде відстрочене (тимчасово призупинене) введення на колишніх тимчасово окупованих територіях норм деяких нормативно-правових актів (наприклад, у частині військової служби та роботи в центральних органах виконавчої влади, правоохоронних та судових органах, спеціальних службах, електоральної участі у парламентських та президентських виборах тощо)» (Pereosmyslennia deokupatsiinoi polityky..., 2020, p. 151). Причина такої відстрочки полягає в тому, 
що населення нині окупованих українських територій зазнало гібридної агресії у інформаційному просторі й тривалий час знаходилося під дією деструктивних імперативів кремлівської пропаганди, воно потребуватиме комплексної реабілітації у формі повернення в систему координат української культурноціннісної матриці. Ефективна розбудова миру на деокупованих та реінтегрованих територіях передбачає поширення українських культурноціннісних домінант, українізацію інформаційно-культурного простору та освітньо-виховної системи. Найкращі зразки масових видів культури (кіно, музика, література, театр) повинні отримати широкі канали розповсюдження (радіо, телебачення, концерти, фестивалі, вистави, конкурси) у регіонах, де впродовж багатьох років відбувалося ціленаправлене витіснення української культури (Semchynskyy, 2018, p. 160-161).

Варто врахувати, що реалізація традиційних стратегій розбудови миру буде ускладнена опором з боку РФ, підконтрольних їй екстремістських груп і шпигунської мережі, які залишаться на деокупованій території з метою дестабілізації ситуації, саботажу господарської реконструкції, а також терористичної діяльності. Гуманітарна інтервенція з боку Російської Федерації перешкоджатиме успішній реінтеграції нині окупованих територій до українського соціокультурного інформаційного простору. Тож перспективи розбудови миру залежатимуть від того, як українська держава гарантуватиме тривалий мир на деокупованих територіях, на своїх умовах провадитиме їхню успішну реінтеграцію та розвиток у складі України й унеможливить рецидив гібридної агресії і конфлікту у майбутньому.

\section{Висновки}

Серед факторів ефективності хорватської стратегії розбудови миру варто виділити здатність держави створити необхідні умови для повернення біженців, вести діалог з переселенцями і задовольняти їхні потреби, а також наявність суспільного консенсусу щодо пріоритету цілісності держави і засобів для відновлення суверенітету над усією їі територією.

Хорватський досвід є надзвичайно корисним для України, проте не всі засоби деокупації та реінтеграції територій, що мали успіх у хорватському кейсі, можуть бути настільки ж ефективними в сучасних українських реаліях.

У процесі реінтеграції нині окупованих українських територій можливе застосування окремих елементів хорватської моделі розбудови миру. Перш за все це стосується комплексу заходів щодо роззброєння та повернення до мирного життя учасників незаконних збройних формувань і сприяння реалізації прав і свобод внутрішньо переміщених осіб з тимчасово окупованих територій України та створення умов для добровільного повернення таких осіб до покинутого місця проживання (реінтеграція) або інтеграції за новим місцем проживання в Україні. 
Ефективна розбудова миру на деокупованих та реінтегрованих територіях передбачає поширення українських культурно-ціннісних домінант, українізацію інформаційно-культурного простору та освітньо-виховної системи.

У перспективі варто дослідити, як оздоровлення культурно-ціннісної матриці мешканців регіону та успішна реінтеграція нині окупованих територій до українського соціокультурного інформаційного простору сприятиме розбудові позитивного миру на основі справедливості.

\section{References:}

1. 'Bezpechna reintehratsiia - pro shcho ydetsia?' [Safe reintegration - what is it about?]. (2019). Ukrainska Helsinska spilka s prav liudyny [Ukrainian Helsinki Human Right Union], [online]. Available at: https://helsinki.org.ua/articles/bezpechnareintehratsiia-pro-shcho-ydet-sia-mova/.

2. Bozhichevich, H. (2020). Rozbudova dialohu. Vybrani pryklady roboty $z$ prymyrennya u Khorvatiyi [Dialogue building. Selected examples of reconciliation work in Croatia]. Kyiv: Duh i Litera.

3. Demeschuk, A. (2018). 'Myrna reintehratsiya Skhidnoyi Slavoniyi, Baran'yi ta Zakhidnoho Sremu do Khorvatiyi (1995-1998 rr.)' [Peaceful reintegration of Eastern Slavonia, Baranja and Western Srem into Croatia (1995-1998)]. Etnichna istoriia narodiv Yevropy, issue 54, pp. 175-180.

4. Levchenko, O. (2017). 'Chomu Khorvatii vdalosia: yak kraina povernula terytorii pislia rokiv okupatsii ta hibrydnoi viiny' [Why Croatia succeeded: how the country regained territory after years of occupation and hybrid war]. Yevropeiska pravda, [online]. Available at: https://www.eurointegration.com.ua/articles/2017/08/4/7069423/.

5. Levchenko, O. (2018). 'Erdutska uhoda vs Minski domovlenosti: khorvatskyi dosvid dlia Donbasu' [Erdut Agreement vs Minsk Agreements: Croatian Experience for Donbass]. Zakhidnyi front [The Western front], [online] Available at: https://zahidfront.com.ua/news/Erdutska-ugoda-vs-Minski-domovlenosti-xorvatskijdosvid-dlya-Donbasu.html.

6. 'Pereosmyslennia deokupatsiinoi polityky Ukrainy $\mathrm{v}$ ramkakh hibrydnoi viiny rosii proty Ukrainy: Analitychna dopovid' [Rethinking Ukraine's deoccupation policy in the framework of Russia's hybrid war against Ukraine: Analytical report]. (2020). Ukrainian Prism Foreign Policy Council, [online]. Available at: http://prismua.org/en/24-112020/?fbclid=IwAR0i7naNQSol7wCPhL0sC6HmNPXjCwn_dlG7kIbfbBAySU7D9LAJpjn yjes.

7. Prypynennia $i$ postkonfliktne vrehuliuvannia separatystskykh konfliktiv: inozemnyi dosvid i vysnovky dlia Ukrainy: Analitychna zapyska [Cessation and post- 
conflict settlement of separatist conflicts: foreign experience and conclusions for Ukraine. Analytical note]. (2017). Kyiv: National Institute for Strategic Studies.

8. Semchynskyy, K. (2018). 'Kulturno-tsinnisnyi vymir post-konfliktnoho prymyrennia na Donbasi' [Cultural and value dimension of post-conflict reconciliation in Donbass]. Kultura i mystetstvo v suchasnomu sviti [Culture and Arts in the Modern World], issue 19, p. 154-164. DOI: 10.31866/2410-1915.19.2018.141368.

9. Tarasov, Y. (2019). 'Viina na Donbasi ta dosvid Khorvatii. Detalna rozpovid uchasnytsi reintehratsii Podunavia' [The war in Donbass and the experience of Croatia. Detailed story of a participant in the reintegration of the Danube region]. Radio Svoboda, [online]. Available at: https://www.radiosvoboda.org/a/khorvatsyi-variantmyrnoi-reintergatsii/30318036.html?fbclid=IwAR3Zw6P7jzGtvJL-b4tLJQ04o3jVWD56EsliqS7TMFjuBTHbzt0KCVF4DM.

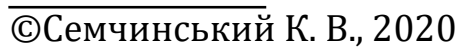

